\title{
In vitro characterisation of Bovine Leukemia Virus capsid protein self-assembly
}

\author{
Gonzalo Obal ${ }^{1 *}$, Jean Lepault², Federico Carrion', Lorena Tome1', Gonzalo Moratorio', Gonzalo Rama1', \\ Sergio Bianchi ${ }^{1}$, Otto Pritsch ${ }^{1}$ \\ From 15th International Conference on Human Retroviruses: HTLV and Related Viruses \\ Leuven and Gembloux, Belgium. 5-8 June 2011
}

Bovine leukemia virus (BLV) and Human T-cell Leukemia virus (HTLV) are oncogenic retroviruses of the genus Deltaretrovirus, and affects cattle and human respectively. BLV is the etiologic agent of Enzootic Bovine Leukemia and infects B-cells of dairy/beef cattle generating a life-long infection leading to economic losses and commercial restraints. In common with other retroviruses, formation of a functional core structure during morphogenesis of BLV/HTLV viral particles is essential for infectivity. In this process, thousands of capsid (CA) molecules self-assemble to form a shell which encases the genome. The assembly mechanism of BLV-CA protein assemble to form mature-type core in vivo and in vitro are unknown, and more broadly, they are yet poorly understood in Deltaretrovirus, despite important advances utilizing HTLV-CA protein. We recently started in vitro analysis of the characteristics/ requirements of BLV-CA protein assembly and developed a turbidimetry-based assembly assay using the purified recombinant BLV-CA protein. Here we show the examination of assembly under a variety of environmental and physical, including near physiological, conditions. Specifically, the effect on self-assembly triggering and kinetics was analysed for protein concentration, $\mathrm{pH}$, ionic strength, temperature, phosphate and polyphosphates. The influence of both independent $\mathrm{N}$-terminal and $\mathrm{C}$-terminal domains on oligomerization kinetics was also assessed. In parallel, we performed electron microscopic analysis of assembly products in order to evaluate the physical characteristics of the material formed under these conditions. This work provides the first description of the BLV capsid protein assembly properties,

\footnotetext{
* Correspondence: gobal@pasteur.edu.uy

'Unidad de Biofísica de Proteínas, Institut Pasteur de Montevideo, Montevideo, 11400, Uruguay

Full list of author information is available at the end of the article
}

which may also be of relevance for understanding other Deltaretrovirus assembly characteristics.

\begin{abstract}
Author details
${ }^{1}$ Unidad de Biofísica de Proteínas, Institut Pasteur de Montevideo, Montevideo, 11400, Uruguay. ${ }^{2}$ CNRS, Laboratoire de Virologie Moléculaire et Structurale, Gif-sur-Yvette, 91198, France.
\end{abstract}

Published: 6 June 2011

doi:10.1186/1742-4690-8-S1-A30

Cite this article as: Obal et al:: In vitro characterisation of Bovine

Leukemia Virus capsid protein self-assembly. Retrovirology 2011 8(Suppl 1):A30.
Submit your next manuscript to BioMed Central and take full advantage of:

- Convenient online submission

- Thorough peer review

- No space constraints or color figure charges

- Immediate publication on acceptance

- Inclusion in PubMed, CAS, Scopus and Google Scholar

- Research which is freely available for redistribution

Submit your manuscript at www.biomedcentral.com/submit
() Biomed Central
C Biomed Central

() 2011 Obal et al; licensee BioMed Central Ltd. This is an open access article distributed under the terms of the Creative Commons Attribution License (http://creativecommons.org/licenses/by/2.0), which permits unrestricted use, distribution, and reproduction in any medium, provided the original work is properly cited. 